\title{
Runoff variations in Lake Balkhash Basin, Central Asia, 1779 to 2015, inferred from tree rings
}

\footnotetext{
${ }^{1}$ Panyushkina I.P., ${ }^{1}$ Meko D.M., ${ }^{2,3}$ Macklin M.G., ${ }^{4}$ Toonen W.H.J., ${ }^{5}$ Mukhamadiev N.S, ${ }^{6}$ Konovalov V.G., ${ }^{5}$ Ashikbaev N.Z, ${ }^{5}$ Sagitov A.O.
}

${ }^{1}$ Laboratory of Tree-Ring Research, University of Arizona

1215 E. Lowell St., Tucson, AZ, 85721 USA

${ }^{2}$ School of Geography and Lincoln Centre for Water and Planetary Health University of Lincoln, LN6 7TS Lincoln, United Kingdom

${ }^{3}$ Innovative River Solutions, Institute of Agriculture and Environment Massey University, Private Bag 11 222, Palmerston North, 4222 New Zealand

${ }^{4}$ Dept. Geography and Earth Sciences, Aberystwyth University

Llandinam Building, Penglais Campus, SY23 3DB Aberystwyth, United Kingdom

${ }^{5}$ Z.H. Zhiembaev Research Institute of Plant Protections and Quarantine,

Kazybek Bi 1, Almaty, 050070 Kazakhstan

${ }^{6}$ RAN Institute of Geography

Staromonetnyi Pereulok 29, Moscow, 119017 Russia

Corresponding author: Irina Panyushkina

Email: ipanyush@email.arizona.edu

Phone: +1 520245730 


\begin{abstract}
Long highly-resolved proxies for runoff are in high demand for hydrological forecasts and water management in arid Central Asia. An accurate $\left(\mathrm{R}^{2}=0.53\right)$ reconstruction of October-September discharge of the Ili River in Kazakhstan, 1779-2015, is developed from moisture-sensitive tree rings of spruce sampled in the Tian Shan Mountains. The fivefold extension of the gauged discharge record represents the variability of runoff in the Lake Balkhash Basin for the last 235 years. The reconstruction shows a 40 yr long interval of low discharge preceded a recent high peak in the first decade of the 2000s followed by a decline to more recent levels of discharge not seen since the start of the gauged record. Most reconstructed flow extremes $( \pm 2 \sigma)$ occur outside the instrumental record (1936-2015) and predate the start of large dam construction (1969). Decadal variability of the Ili discharge corresponds well with hydrological records of other Eurasian internal drainages modeled with tree rings. Spectral analysis identifies variance peaks (highest near 42 yr) consistent with main hemispheric oscillations of the Eurasian climatic system. Seasonal comparison of the Ili discharge with sea-level-pressure and geopotential height data suggests periods of high flow likely result from the increased contribution of snow to runoff associated with the interaction of Arctic air circulation with the Siberian High-Pressure System and North Atlantic Oscillation.
\end{abstract}

\title{
Keywords
}

Climate change impacts; Water resources; Ili River runoff; Discharge proxy; Dendrochronology; Picea schrenkiana; Tian Shan Mountains; Kazakhstan

\section{Acknowledgements}

This work was supported by the British Council Program’s Newton-al Farabi Institutional Links award \#172727191 to M.G. Macklin. The development of the tree-ring network was funded in part by U.S. National Science Foundation BCS award \# 1122359 to I.P. Panyushkina. Support for the Twentieth Century Reanalysis Project dataset is provided by the U.S. Department of Energy, Office of Science Innovative and Novel Computational Impact on Theory and Experiment program, Office of Biological and 
Environmental Research, and by the National Oceanic and Atmospheric Administration Climate Program Office.

\section{Introduction}

Climate impact on human conflicts is well recognized (Zhang et al. 2007; Hsiang et al. 2013; Siegfried and Bernauer 2015). Various studies show long-term drying and warming trends contribute greatly to widespread and long droughts that create inevitable stress on the water resources of arid-land regions like the American Southwest, Middle East, Mongolia, and Southeast Asia (e.g. Buckley et al. 2010; Siegfried et al. 2011; Meko and Woodhouse 2011; Pederson et al. 2013; Kelley et al. 2015; Touchan et al. 2016). Water supply shortfalls in conjunction with population growth and economic development are a tangible problem for Central Asian countries situated across the internal drainage systems of Inner Eurasia (Bernauer and Siegfried 2008). Weak environmental policies and political tensions over water withdrawals increasingly impact Asian geopolitics and may create a new international conflict zone (Abdolvand et al. 2015). Management of water resources in the region is challenged by great uncertainties regarding the response of water supply to climate change. Lack of information on the changes in spatial-temporal domains of runoff variability before the last 60-70 years of instrumental observations hinders for socioeconomic response to water stress.

Unfortunately, the instrumental discharge data do not track the regional effects of climate change on basin-scale runoff in Central Asia. Regional runoff in Central Asia derives from glacier melt and annual precipitation. Key studies based on instrumental data indicate that runoff in this region has remained unchanged or has declined only slightly (1-2\%) over the period 1940-2005 while regional temperature has a warming trend (Aizen et al. 1996; Konovalov and Pimankina 2016). The measured contribution of glacier melt has been increasing, while snowmelt significantly decreased over 1940-1991 (Konovalov and Pimankina 2016). Glacier mass-balance modeling estimates an 18\%27\% decrease in the glacier area across the Tian Shan since 1961 (Farinotti et al. 2015). Precipitation over the larger region of Central Asian drainages is decreasing (Lammers et al. 2001; Bothe et al. 2012). The primary source of moisture for runoff is cold season precipitation and spring storms embedded in the midlatitude westerlies, with some 
contributions from the higher latitudes (Lydolf 1977). Critical alteration of the prevailing hemispheric circulation under ongoing climate change considerably impacts the seasonal dynamics of temperature and precipitation (Cohen et al. 2001; Jeong et al. 2011), and the annual and seasonal distribution of runoff in Central Asia.

In winter, Central Asia is under the influence of the Siberian High Pressure System (SH), a semi-permanent anticyclone centered over Mongolia that forms in response to radiative cooling of the air above snow-covered Eurasia in October and remains until April (Lydolf 1977). During a strong SH the region west of and outside the SH source area experiences high cyclonic activity, with resulting fall and spring storms delivering excess precipitation. The variability of SH intensity and its teleconnections have been linked to large changes in patterns of fall snow, heavy snowfall events, severe cold-surge outbreaks and frequency of spring storms over Inner Eurasia (Panagiotopoulos et al. 2005; Jeong et al. 2011). A dramatic SH weakening - unprecedented in the past 400 years - has been found for the recent period 1978-2001 from analysis of tree rings (D’Arrigo et al. 2005).

This study establishes a long-term context for natural variability of Central Asian runoff. The historical network of streamflow gauge observations in Central Asia begins in the late 1930s, but the quality of the network deteriorated severely in the early 1990s after the collapse of the Soviet Union and the development of new governing sovereignties in the region. Long high-resolution proxies of runoff derived from tree-ring archives could provide a valuable benchmark to study the changes in spatial-temporal domains of runoff variability and linkages with long-term climate variability and climate change (e.g., Woodhouse et al. 2006; Meko and Woodhouse 2011; Agafonov et al. 2016; Cheng et al. 2016).

The main goals of this study are to 1) reconstruct annual discharge of the Ili River with tree rings and extend the instrumental hydrological records for several centuries, and 2) describe the spatial-temporal domains of discharge variability and its relationship to the hemispheric-scale atmospheric circulation. The Ili River is the largest water artery of the Lake Balkhash Basin and the principal water source for southern Kazakhstan, which has a population of over 2,685,000 and the largest urban node of Central Asia -Almaty City (1,703,485 people). A long-term record of Ili discharge can contribute to better 
understanding of the response of runoff from the internal drainages to climate change, and to improved basin-scale management of water resources through more accurate estimation of water supply in Kazakhstan and the broader region of Central Asia.

\section{Study Area and Sites}

The Lake Balkhash Basin, comparable in size to the Aral-Caspian and Tarim basins, is a closed basin in Inner Eurasia. Most rivers in the basin have headwaters in China and Kyrgyzstan, and flow from south to north through Kazakhstan. Annual runoff of the Lake Balkhash Basin is $0.26-0.36 \mathrm{~km}^{3} / \mathrm{y}, 0.12-0.14 \mathrm{~km}^{3} / \mathrm{y}$ of which comes from glacial melt (Mamatkanov et al. 2006; Kuzmichenok et al. 2009). The hydrological regime of the watershed is dominated by glacier and snow melt water with high flows between May and September, and highest peaks in July and August. While the glacier share of runoff is estimated to range from ca. $10 \%$ to $40 \%$, there is large uncertainty in estimation of glacial area and glacier volume of the hundred small glaciers in the basin (Sorg et al. 2012; Farinotti et al. 2015; Konovalov and Pimankina 2016).

The Ili River (length 1,439 km, watershed area $140,000 \mathrm{~km}^{2}$ ) is formed by the confluence of the Tekes and Kunges rivers in Xinjiang, China (Fig. 1). Both of these rivers have snow- and glacier-dominated headwaters. The average annual discharge of the Ili is about $480 \mathrm{~m}^{3} / \mathrm{s}$. The main tributaries of the Ili River that drain the Zailiyskiy Alatau Range of the Tian Shan Mountains in Kazakhstan are the Charyn, Keskelen, Talgar, Turgen and Chilik Rivers. These tributary catchments contain nearly one hundred small glaciers whose areas range from $4 \%$ to $26 \%$ of the area of the watershed, and which contribute from 17\% (Keskelen River) to 56\% (Talgar River) of the summer runoff (Vilesov and Uvarov 2001). The total area of these small glaciers is presently ca. 253 $\mathrm{km}^{2}$, which is $53.6 \mathrm{~km}^{2}$ less than for the period 1946-1975 (Konovalov and Pimankina 2016). The highest discharge peak in July is ca. $600 \mathrm{~m}^{3} / \mathrm{s}$ and the lowest flow in January is ca. $200 \mathrm{~m}$ /3 s (Fig. 2a). The Ili River runoff has been altered since 1970 by construction of the Kapchagay Dam and Reservoir (Fig. 1). The dam was completed in 1969 and the reservoir filled over the next 20 years.

High river flow is consistent with warm air temperature, upsurge of glacier melt, and intensification of the southwestern cyclonic circulation driven by the Siberian High 
oscillations (Aizen et al. 1997; Jeong et al. 2011). The extremely continental temperate climate of the region originates from the latitudinal position and strength of the westerlies, which govern the intensity and extent of the Siberian High (Cohen et al. 2001). Historical observations at the Almaty weather station, near the center of the Ili River Basin, give a January mean temperature of $-6.7^{\circ} \mathrm{C}$ and July mean temperature of $+23.3^{\circ} \mathrm{C}$. Annual precipitation varies from $250 \mathrm{~mm}$ to $800 \mathrm{~mm}$ and its spatial pattern depends on orography. Snowpack accumulates from November to February (ca. 30-50 mm per month). Maximum precipitation occurs in April-June in warm and moist air advected from the west. Fall-winter precipitation is driven by the interaction of the Siberian High and the westerly jet stream.

Tree rings of Picea schrenkiana (Fisch. \& C.A. Mey.), known by the common name of Schrenk's spruce, are used in the discharge modeling. This spruce is a widely distributed conifer species in the mountain forests of Central Asia. The study sites are situated in the northern part of the Tian Shan Mountains, southern Kazakhstan. We developed a network of 11 sites in the Zailiyskiy Alatau Range (recently renamed the Trans-Ili Range), which is in the middle of the Ili Basin. The sites are located in the catchments of five tributaries of the Ili River: M. Almatinka, Talgar, Issyk, Turgen and Chilik (Fig. 1, Table 1). Preliminary sampling started in 2001 and the majority of sites were collected in 2015. Our sampling strategy targeted spruce growing under moisture stress at low and high elevations along a $250 \mathrm{~km}$ west-east transect at elevations 700$2700 \mathrm{~m}$ asl (Table 1). We sampled five open-canopy stands at low elevations on steep slopes of mountain gorges, and six stands on steeply sloping rock outcrops at the upper tree-line ecotone.

The growing season of spruce starts in April and ends by October at low elevations, and is shorter by about 4-7 weeks at the upper tree-line (Borscheva 1986). The temporal offset of growing season with elevation relates to the response of spruce phenology to altitudinal patterns of fall temperature and length of the dry season, which is fall-winter (Kozhevnokova 1986; Borscheva 1988). We are not aware of any comprehensive studies of altitudinal patterns of climate, plant phenology and physiology in the Ili catchment conducted since the 1990s. Generally, cold season temperature and summer drought limit the growth of winter-dormant conifers in the mountain forests of 
arid lands. Radial growth rate is high in March-May and decline in summer following the July-Aug dry period (Wang et al. 2005; Goulden et al. 2012).

\section{Data and Methods}

\subsection{Tree-ring data}

Two cores per tree were extracted with an increment borer at breast height (120$140 \mathrm{~cm}$ ) were sampled from 15-20 trees at each site. The cores were shipped to the laboratory of Tree-Ring Research, University of Arizona, where they were processed for tree-ring width measurement and crossdating (Stokes and Smiley 1996). Ring widths were measured on mounted and sanded wood surfaces using a Lintab measuring stage system with $0.01-\mathrm{mm}$ precision. Ring width series were crossdated visually with plots, and dating was checked with correlations using the computer program COFECHA (Holmes 1983).

Tree-ring index chronologies were developed using the conventional approach, whereby crossdated ring width series are detrended by the ratio method after first fitting the data with a cubic smoothing spline with a frequency response of 0.50 at a wavelength of 2/3 the sample series length (Cook and Peters 1981). The individual detrended series were combined into a standard chronology using a bi-weight robust mean, and the Briffa method for variance stabilization was applied to adjust for variance changes in the chronology due to time-varying sample size (Osborn et al. 1997). It is well recognized that chronology sample size decreases back in time and that tree-ring variance may greatly increase in poorly replicated parts of a chronology. Commonly a sample size of 510 trees is sufficient replication for any given time interval (Shiyatov et al. 1990, p. 133). Another measure the sufficiency of replication is the expressed population signal (EPS), which measure the degree to which a chronology of a particular sample size represents the population growth signal in a hypothetical infinite-size chronology (Wigley et al. 1984). An EPS of 0.85 is frequently used as an arbitrary threshold for adequate replication in dendroclimatology. Tree-ring chronologies were computed using program ARSTAN (Cook et al. 2007). To increase sample size and so extend the usable length of chronologies, tree-ring series from 2-3 closely locate sites with similar growth conditions and high inter-series correlation were combined to form composite chronologies. Table 2 
lists statistics for five composite ring-width chronologies developed from the 11 collection sites.

\subsection{Hydroclimatic data}

For climatic interpretation we used monthly temperature and precipitation from the Almaty weather station (\#36879, 432' $\mathrm{N}, 76^{\circ} 93^{\prime} \mathrm{E}, 895 \mathrm{~m}$ asl) located in the $\mathrm{M}$. Almatinka River catchment (Fig. 1), which is representative of the Lake Balkhash Basin (Zhou et al. 2017). Monthly climate data were downloaded from the GHCN-M v.2/v.3 adjusted database, accessed from the U.S. National Climatic Data Center (www.ncdc.noaa.gov). Discharge records from the following gauge stations are used in the study: U. Kapchangay (\#90210, 44 13'N, 76² 98'E, $428 \mathrm{~m}$ asl) and Turgen (\#90260, $43^{\circ} 27^{\prime} \mathrm{N}, 77^{\circ} 20^{\prime} \mathrm{E}, 1199 \mathrm{~m}$ asl). Monthly observations of instrumental discharge for the period 1936 to 1985 were accessed through ARC (Arctic-net) and SHI hydrological databases of the Former Soviet Union (Bodo 2000). Because Ili River flow has been strongly affected by reservoir operations since 1970, subsequent discharge measurements do not reflect the natural variability of runoff, and cannot be directly applied to study the strength of relationship of discharge to tree rings. To solve this problem we adjusted the U. Kapchagay observations to the gauge record of the Ili River tributary with linear regression.

The Ili river discharge at the U. Kapchagay gauge is significantly correlated with discharge of small tributaries such as the Talgar, Issyk and Turgen Rivers $(\mathrm{R}=0.66$, $\mathrm{p}<0.05$ ). Previous studies of hydrograph measurements of runoff show that discharge of the Turgen River strongly tracks variations of annual discharge of the Ili’s main tributaries and small rivers flowing from the Zailiyskiy Alatau to the Lake Balkhash Basin (Konovalov and Pimankina 2016). Reservoir-adjusted mean annual flow (OctoberSeptember) of the Ili at U. Kapchagay was approximated by fitting a linear regression model to gauge data of Turgen River flow, which is unaffected by dam or water reservoirs. The regression model, calibrated on the period 1937-1969, is

$$
\hat{y}=\hat{a}_{o}+\hat{b}_{1} x_{1}
$$

where $x_{1}$ is Turgen River discharge $\left(\mathrm{m}^{3} / \mathrm{s}\right) ; \hat{a}_{0}$, and $\hat{b}_{1}$ are the estimated regression constant and coefficient, and $\hat{y}$ is the estimated Ili discharge $\left(\mathrm{m}^{3} / \mathrm{s}\right)$ for the hydrological 
year (previous-year October to current-year September average). The fitted regression model for annual discharge adjustment, $\hat{y}=80.37603+54.10870 x_{1}$, has the following statistics for 1937-1969 (32 yr) calibration period: $\mathrm{R}^{2}=0.49, \mathrm{R}^{2}$ adj. $=0.48, \mathrm{~F}(1,30)=28.17$ $(\mathrm{p}<0.0001)$. Positive results from cross-validation and an analysis of residuals confirmed the good fit of the model. The residuals are approximately normally distributed and have no significant dependence on the fitted values. Figure 3 shows the record of adjusted discharge of the Ili River at U. Kapchagay that combines the original U. Kapchagay gauge series from 1937 to 1969 and the predicted series for the interval 1970-1985.

\subsection{Analysis of relationship between ring index, climate and discharge}

Principal components analysis (PCA; Jolliffe 2002) was applied to the composite tree-ring chronologies (Table 2) to reduce redundancy and to derive orthogonal variables for use as predictors in the reconstruction model. This approach has been widely used in dendrohydrologic reconstruction (e.g., Meko et al. 2001; Woodhouse et al. 2006; Agafonov et al. 2016). The PCA was computed on the correlation matrix of the five composite tree-ring chronologies for the common period 1779 -2015 (Table 3). The start year of feasible reconstruction with the principal components (PCs) as predictors is 1779 . While this start year predates the EPS threshold year for some chronologies (Table 2), use of the PCs rather than individual chronologies effectively strengthens the sample size and counters the low sample depth of some individual chronologies in the interval 17791835 (Table 2).

The climatic signal and seasonal window of climate response of the of orthogonal tree-ring series were identified with program Seascorr, which uses Monte Carlo simulations to assess significance of Person correlations and partial correlations between tree-ring and climate variables (Meko et al. 2011). Climate data for the Almaty station, 1960-2014, was used in this analysis. Seascorr was also applied to evaluate the dependence of discharge on seasonal climate using instrumental data from the $\mathrm{U}$. Kapchagay gauge (1936-1985) and the Almaty weather station.

\subsection{Discharge reconstruction model}

An optimal window for discharge reconstruction was selected by stepwise 
regression (Weisberg 1985) of adjusted Ili River discharge at the U. Kapchagay gauge on selected tree-ring PCs with demonstrated seasonal windows of climatic signal. Variables were entered into the model with $p$-to-enter and p-to-remove thresholds of 0.05 and 0.10 (Weisberg 1985). The regression model was re-calibrated, and subjected to analysis of residuals to identify possible violations of regression assumptions (Weisberg 1985), and validated to check performance on data not used in fitting. The combined calibration and verification period was limited to the interval 1937-1985, which is the most reliable part of the gauge observations. Cross-validation (Michaelsen 1987) was done at each step to avoid model over-fitting, such that an additional step in the stepwise procedure was accepted only if that step yielded an increase in skill as measured by the reduction-oferror statistic (RE; Fritts et al. 1990). Mallows's Cp statistic (Mallow 1973) was used as an additional safeguard against overfitting. The strength of the reconstruction model was measured with regression $\mathrm{R}^{2}$, and the prediction sum of squares (PRESS) statistics was used as a conservative estimate of prediction error (Weisberg 1985).

\subsection{Analysis of reconstructed discharge variance}

Years with reconstructed discharge more than $\pm 2 \sigma$ from the instrumental mean $\left(457 \mathrm{~m}^{3} / \mathrm{s}\right)$ were classified as extremes. These low and high thresholds are $323 \mathrm{~m}^{3} / \mathrm{s}$ and $591 \mathrm{~m}^{3} / \mathrm{s}$, respectively. Low-frequency variations of discharge were summarized by annual discharge smoothed with a 10-year Tukey filter (Blackman and Tukey 1958). Variations of reconstructed discharge in the frequency domain were summarized by smoothed periodogram spectral analysis (Bloomfield 2000) and wavelet analysis (Torrence and Compo 1998, Grinsted et al. 2004). For spectral analysis, the raw periodogram was smoothed with a succession of Daniell filters such that main spectral features emerged with a known bandwidth and confidence interval. Confidence intervals were not adjusted for multiple comparisons (e.g., no Bonferroni adjustment). For wavelet analysis, the Morlet wavelet (6.0/6) was applied to summarize changes in amplitude of discharge oscillations as a function of time and frequency. Cross-wavelet analysis (Grinsted et al. 2004) was applied to test the coherency of reconstructed Ili discharge with and index of the Siberian High (D’Arrigo et al. 2005). Coherency is analogous to 
correlation as function of frequency. Significant levels of coherency were defined with Monte Carlo testing (Grinsted et al. 2004).

Linkage of reconstructed discharge to atmospheric circulation anomalies was studied with composite maps of $500 \mathrm{mb}$ geopotential height and surface pressure anomalies for the winter (October-February) and spring (March-June) seasons using the NOAA/ESRL mapping tool (http://www.esrl.noaa.gov/psd/) and NCEP/NCAR Reanalysis data (Compo et al. 2011). The connection between the reconstructed discharge and main modes of upper air circulation (Barnston and Livezey 1987) was examined with correlation analysis. Monthly time series of the Scandinavian index, Polar Eurasian Pattern, North Atlantic Oscillation (NOA) and Arctic Oscillation index (AO) are downloaded from the NOAA/ESRL website. A SH index reconstructed from tree rings by D'Arrigo et al. (2005) was used to infer possible meteorological conditions impacting the snow pack and temperature across the study region for the period 1599-2004. Correlation of the reconstructed time series with CRU 3.24 gridded data for selfcalibrating Palmer Drought Severity Index (scPDSI; Wells et al. 2004) was calculated for the interval 1901-2014 and plotted in KNMI Climate Explorer (www.climexp.knmi.nl).

\section{Results and Discussion}

\subsection{Tree-ring chronologies, PCA and climatic signal in tree rings}

Composite ring-width chronologies for five locations were developed from 11 collection sites, each having 35-64 total series, with individual site chronologies spanning 237-323 years. Inter-series (between tree) correlations for the chronologies vary from 0.58 to 0.64 , and are significant at $p<0.01$. The tree-ring chronologies represent growth of spruce near the lower tree-line (Issyk), mid-elevation forest sash (Chilik, M. Almatinka) and the upper tree-line (Assy and Turgen). With one exception, the composite chronologies correlate significantly $(0.13 \leq r \leq 0.60, p<0.05)$ with each other. The exception is the M. Almatinka River chronology, which differs from those in neighboring valleys (Issyk, Turgen, and Assy) but correlates significantly with another mid elevation site $250 \mathrm{~km}$ eastward, in the Chilik River basin (Fig. 1). M. Almatinka is located in the vicinity of Almatinskoye Lake; growth conditions are dry and cold because the trees 
grow on steep rocky slopes next to the cold glacial water-fed lake. The temperature regime at the M. Almatinka site therefore differs from that of the typical mid-elevation climatic setting. All chronologies show considerable interannual variations in ring-width. Statistics for the developed tree-ring chronologies are listed in Table 2. The five composite tree-ring chronologies used in subsequent PCA analysis attain EPS $>0.85$ by 1779.

PCA of the tree-ring chronologies shows a strong common signal in these five chronologies and suggests growth contrasts are related to a different moisture signal at low, middle and high elevations. The growth contrasts reflect different temperature and precipitation patterns at the various elevations (see Study Area and Site section). PC1 accounts over $52 \%$ of the tree-ring variance and has high positive high weights on most chronologies and a slightly lower weight on M. Almatinka (Table 3). PC2 describes about $20 \%$ of the explained variance, and mainly contrasts $\mathrm{M}$. Almatinka with the other chronologies. This contrast is likely due to the atypical cold temperature regime at $\mathrm{M}$. Almatinka. PC3 accounts for $13 \%$ of the variance, and is a contrast in length of growing season at the lower tree-line and the remaining locations. PC4, accounting for $10 \%$ of the variance, is primarily a contrast between the dry sites at high and low elevations (see table 2 for elevation reference).

Seascorr results for correlation of tree-ring PCs against monthly and seasonal temperature and precipitation at the Almaty station show a variety of seasonal climate linkages of spruce growth (Fig. 4). Results are shown for only those PC's subsequently found to enter as predictors in stepwise reconstruction of discharge (PCs 1, 3 and 4). PC1 is negatively correlated with cold season precipitation from the previous year fall to January-February current year. Reduced growth is related to the late start of growing season, and reflects significant impact of snowpack. PC3 correlates significantly and positively with the warm season (May-September) precipitation and temperature. PC4 reflects importance of summer drought to growth variability; correlations with precipitation are positive for the driest months of the growing season (July-September). Snow, warm summers and summer drought play central roles influence tree growth, and also the hydrology through the influence on water sources for seasonal flows. In the semiarid climate of the Lake Balkhash basin, fall and spring storms yield most of the 
precipitation (Panagiotopoulos et al. 2005), while July-September is hot and dry. The highly significant climatic signals revealed by Seascorr support the effectiveness of PCA in condensing the hydrologic signals in these tree-ring series for later use in hydrological modeling and reconstruction.

Previous studies indicate that both temperature and precipitation are limiting factors to spruce growth in the Tian Shan Mountains (Borscheva 1988; Wang et al. 2005; Solomina and Maksimova 2010). A warm spring and early snowmelt favor an early onset of the growth season and a high rate of tree-ring growth (Wang et al. 2005). High precipitation in the previous fall and winter prompts greater retention of soil moisture after snowmelt, which helps to cope with summer drought, but can negatively impact growth by shortening the growing season (Kozhevnikova 1982; Borscheva 1988). The moisture signal in tree rings of Schrenk's spruce has been discussed in relation with previous fall-winter precipitation, and has been successfully used in reconstruction of precipitation, PDSI, water balance and streamflow (e.g. Yuan et al. 2007; Solomina and Maksimova 2010; Konovalov and Maksimova 2012; Chen et al. 2015, 2016; Zhang et al. 2017b).

\subsection{Streamflow reconstruction of Ili River}

Seascorr results for annual discharge of Ili River at the U. Kapchagay gauge and monthly and seasonal temperature and precipitation from the Almaty station indicate a strong positive relationship between the instrumental discharge and precipitation for previous fall-current summer season (Fig. 5). A negative partial correlation for May temperature indicates negative impact of temperature in that month on flow even after accounting for the covariation between temperature and precipitation. The absence of positive correlations during the warm season suggests that glacier melt is secondary importance to the discharge variations. Warm air temperature increases glacier melt, which could lead to high flows in the Lake Balkhash basin (Aizen et al. 1996), but also is associated with high evapotranspiration, which could reduce runoff. Any glacier-melt signal could therefore have a complicated signature in the runoff of southern Kazakhstan (Konovalov and Pimankina 2016). 
For stepwise regression modeling, we selected a 12-month water year starting in October of the preceding growth year and ending in September of the current growth year since this is the typical water year used by the water management. Stepwise regression of Ili discharge at U. Kapchagay on selected PCs of tree rings for shorter seasonal groupings may account for maximum strength of the hydrological signal, yet the OctoberSeptember water year captures a good hydrological signal $\left(\mathrm{R}^{2}=0.53 \mathrm{p}<10^{5}\right)$. While not as strong as in some temperate western USA basins, such as the Sacramento (Meko et al. 2001) and Colorado (Woodhouse et al. 2006), the hydrological signal in the network of precipitation-sensitive ring widths from the Ili River basin is reasonably strong for deriving a robust and useful to the water management discharge reconstruction. The climatic signature of moisture sensitive growth is complex and integrates a number of positive and negative traits in the spruce physiology. Narrow rings are related to high cold-season precipitation or/and summer drought. Wide rings are the result of a long growth season with adequate precipitation in the warm-season. Decrease of snow cover can spur an early start to the growing season, while summer drought can reduce the growth rate of growth.

The reconstruction model for Ili discharge, fit with stepwise regression and calibrated on the years 1937-1985, is

$$
\hat{y}=\hat{a}_{0}+\hat{b}_{1} x_{1}+\hat{b}_{2} x_{2}+\hat{b}_{3} x_{3}
$$

where $x_{1}, x_{2}$ and $x_{3}$ are scores of PC3, PC1, and PC4, respectively; $\hat{a}_{0}, \hat{b}_{1}, \hat{b}_{2}$, and $\hat{b}_{3}$ are the estimated regression constant and coefficients (see their values in Table 4); and $\hat{y}$ is the reconstructed discharge (October -September). The model was applied to generate reconstructed $\mathrm{d}$ for the interval 1779-2015 (237 yr). Time plots of reconstructed and observed discharge for the 1937-1985 calibration period show no large discrepancies (Fig. 6), and the reconstructed discharge itself appears to be normally distributed (Fig. 7).

Positive and significant cross-validation and calibration statistics indicate high skill and stability of the developed model (Table 4). The model explains over $50 \%$ of discharge variance. The small difference of adjusted $\mathrm{R}^{2}$ and prediction $\mathrm{R}^{2}$ (PRESS statistic), suggests that the model has not been over-fitted, a finding also supported by the computed Mallows's $\mathrm{C}_{\mathrm{p}}$. An analysis of residuals detected no problems with the 
residuals, which appear to be normally distributed and to have no systematic relationship to the fitted values. Autocorrelation in the residuals is not significant.

\subsection{Extremes and variability of reconstructed discharge}

Figure 8 shows the reconstructed October-September discharge of the Ili River. This new discharge record is five times as long as the historical gauged record (Fig. 8, Table 5). The reconstructed discharge has considerable decadal and interannual variability, with most extreme values outside the gauged interval. Only two out of 13 reconstructed flows outside the $\pm 2 \sigma$ interval around the mean $\left(316-594 \mathrm{~m}^{3} / \mathrm{s}\right)$ occur in the period of gauged records. Years of extremely low flows are 1871, 1879, 1846, 1788, 1829 and 1933; year of extremely high flow are 1799, 1851, 2005, 1856, 1808, 1960 and 1816. The driest year was 1871 , when the discharge $\left(239 \mathrm{~m}^{3} / \mathrm{s}\right)$ was only half the historical average $\left(460 \mathrm{~m}^{3} / \mathrm{s}\right)$. The wettest year was 1799 , with a discharge of $728 \mathrm{~m}^{3} / \mathrm{s}$. The record has frequent periods of low flow lasting 25-30 years, and shorter periods of high flow lasting 10-15 years. Periods of low flow were 1825-1850, 1865-1885, 19161938 and 1975-2000, and periods high flow were 1793 -1809, 1850-1857, 1886-1909, 1952-1962 and 2001-2013 (Fig. 8).

The spatial correlation field between the reconstructed series and gridded scPDSI shown in Figure 9 defines the geographical scale of the reconstructed discharge. The reconstruction correlates strongly and positively for the 1901-2014 interval with dry and wet hydrological conditions across the entire Lake Balkhash Basin and Lake Issik Kul Basin (Fig. 9). Aizen et al. (1997) demonstrated high similarities in the anomalies and trends of runoff variability in these two neighboring basins. We conclude that the reconstructed discharge of Ili River represents runoff variability over the Lake Balkhash watershed and more broadly over the internal drainages of Pamyr-Tain Shan Mountain system. The reconstruction therefore represents the hydrological variability of southern Kazakhstan and Kirgizstan for over the past two centuries.

There is a fair agreement of decadal variability of reconstructed Ili discharge and tree-ring reconstructed discharge for the Aksu, Kurshab, and Black Irtysh Rivers, and with the water balance of the Lake Balkhash, Lake Issik Kul and Tarim Basins (Fang et al. 2010; Konovalov and Maksimova 2012; Chen et al. 2015, 2017b; Zhang et al. 2016). 
PDSI and precipitation reconstructions from spruce tree rings in southern Kazakhstan and the broader Pamyr-Tian Shan region are consistently coherent on the decadal scale (Li et al. 2006; Fang et al. 2010; Zhang et al. 2017a, 2017b). However, we find poor agreement of high-frequency (e.g., inter-annual) variability of these reconstructions with reconstructed Ili discharge series; only the decadal variability is similar. The poor coherence at the inter-annual scale could be explained by high summer temperatures and high influx of glacier melt water, and in some cases by mismatch of seasonal windows of the reconstructed variables. For example, Chen et al. (2017a) reconstructed the sum of precipitation from the previous July to current April, a seasonal window that includes only dry-season months and omits months with significant contribution of rains from spring-summer storms.

Spectral analysis of the reconstruction revealed a significant $(\alpha=0.05)$ peak at 42.7 yr (Fig. 10). Other peaks in variance occur near 11.6, 8.0, 5.7, and 2.9 yr. The spectral peaks show some agreement with reported cycles in significant modes of variability of atmospheric circulation indices, such as the Siberian High index (SH), East Asian Winter Monsoon (EAWM), and El Nino-Southern Oscillation (ENSO) (Wu and Wang 2002; Jhun and Lee 2004; D’Arrigo et al. 2005). The 42.7-yr rhythm is evident in the smoothed time plot, which suggests this is an average wavelength of a prominent low-frequency fluctuation with most recent peaks in the 1950s and early 2000s.

Wavelet analysis shows this low-frequency feature most prominent in the late1800s, and indeed the time plot shows a major low near 1870 flanked by major peaks near 1850 and 1895 (Fig. 11). The oscillation of individual wavelets extant in the $19^{\text {th }}$ century completely disappears by the late 1960s, but end effects make interpretation speculative then, as indicated by the cone of interpretability in Fig. 11. Variance is relatively low over 1975-2000, a period when flow stabilizes considerably below the historical average. This reduced-variance interval is a prominent feature not only of Ili River discharge but also of other reconstructed and instrumental runoff records for internal drainages in Inner Eurasia (Aizen et al. 1997; Yuan et al. 2007; Zhang et al. 2016; Chen et al. 2016, 2017a). Interestingly, flow recovers after that segment and begins a high-amplitude swing in which the smoothed curve reaches a peak in the early 
2000s and a low at the end of the record more extreme than any since the late 1800s (Fig. 10).

4.4. Linkages between the reconstructed runoff and climate

The physical mechanisms driving runoff changes in Central Asia are not yet well understood. Temperature appears not to be as important in directly forcing changes as previously thought (Lammers et al. 2001). Aizen et al. (1997) found changes in Central Asian instrumental runoff consistent with the decline of snowpack since 1940. Greater snowpack over broader Eurasia results in positive anomalies of instrumental runoff for the largest Siberian Rivers with headwaters in Inner Asia (Shiklomanov et al. 2013). The Holocene river dynamics of small river catchments in the Ili River Basin and the longterm (multi-century) fluctuations of Lake Balkhash water levels correspond positively to the low-frequency variability of SH intensity (Endo et al. 2012; Takeuchi et al. 2014; Macklin et al. 2015). At the multi-century time scale, a strong SH associated with high water levels, glacier expansion, river channel aggradation and floodplain sedimentation in the Lake Balkhash Basin.

Our reconstruction, consistent with other tree-ring reconstructions of stream flow, PDSI and precipitation, underscores summer drought as an important forcing factor of the runoff variability in Central Asia. Nevertheless, for the season of snow accumulation (October-February), surface pressure over the Ili River basin is significantly positively correlated with surface pressure over a broader region covering the geographical position of the seasonally strong SH pressure system (Fig. 12a). Anomalous strength of the SH likely modulates snow delivery to the Ili River runoff area through changes in storm steering and moisture delivery. Spring moisture as well is important to the river flow (Fig. 2), and its conveyance would also be influence by anomalies in westerly flow (Fig. 12b).

A cross-wavelet transform for reconstructed Ili discharge and SH index reconstructed by D’Arrigo et al. (2005) shows few regions of significant coherency (Fig. 13). The two series are significantly coherent at high frequencies (e.g., periods less than 4 years) only for some isolated times in the $19^{\text {th }}$ and $20^{\text {th }}$ centuries. Furthermore, for those areas of significant coherency the phase is opposite meaning that high flow is 
linked to weak SH. In-phase coherence at periods 30-40 years appears in the late 1900s, and is reflected in the smoothed time series (Fig. 14, bottom), but does not reach statistical significance. Coherency is not consistent through time at any band of wavelengths.

Comparison of reconstructed runoff variations with $500 \mathrm{hPa}$ geopotential height and surface pressure anomalies over Eurasia, and with primary teleconnection modes of Eurasia upper air circulation indicates that the natural runoff variability (extremes, trends and spectral properties) are linked to the interaction of Arctic air circulation with the $\mathrm{SH}$ intensity and negative phase of NAO. Ili discharge correlates negatively with the spring Polar/Eurasian Pattern index and with winter AO; these associations are consistent with a weaker circumpolar vortex during the increased flows (Table 6). The development of the strong SH has been associated with an enhanced East Asian winter monsoon (Jhun and Lee 2004, Panagiotopoulos et al. 2005), which suggests an even more complex relationship of runoff to the atmospheric teleconnections.

Annual discharge is significantly negatively correlated with December-February SH index for 1950-2014 ( $r=-0.32$, $\mathrm{p}<0.05)$. The cross-wavelet results suggest this negative correlation is inconsistent over time, and is driven by high frequencies (Fig. 13). The SH is normally centered over Mongolia, to the east of the study area (Fig. 14a). An extended period of generally low flows (1975-2000) coincided with a weakening of the SH and a shift of the high pressure southward to Tibet (Fig. 14 b). A subsequent period of generally high Ili River discharge (2001-2013) coincided with increased SH intensity and a shift in the position of the winter surface high toward Western Siberia (Fig. 14c). These recent associations are consistent with a positive correlation between runoff and strength of the SH. Therefore, different mechanisms of SH influence on Ili flow may operate at high and low frequencies. The resolution of the reconstruction does not allow examination of summer and winter discharge independently. Yet, we find that snow cover has profound implications for runoff variability in the Lake Balkhash Basin.

\section{Conclusions}


We developed a long annually-resolved record of natural runoff variability in the Lake Balkhash Basin. A 237-year reconstruction of annual discharge for the Ili River identified large, irregular fluctuations in discharge on decadal and multi-decadal time scales, which is valuable new information beyond that contained in the instrumental hydrological data. The recent discharge fluctuations have been exceeded in amplitude by fluctuations before the start of the gauged discharge record. The intensity of the SH and e phase of NAO in the cold season play key roles in the multi-decadal variability of runoff in the Lake Balkhash Basin. On long time scales, high runoff is attributable to intensified SH with excessive cyclonic activity in the fall-winter season and cold winters. Warm winters and dry falls prompted by weak SH result in the low runoff in the long run. But at high frequencies, flow series have no in-phase coherency with the Siberian High dynamics. This is attributed to changes in seasonal discharge. Interannual (highfrequency) variations in runoff may be strongly driven by variations in spring -summer precipitation and temperature.

Overall, the study improves our understanding of the changes in spatial-temporal domains of runoff variability in Central Asia, and highlights the shortcomings of the instrumental discharge record in capturing the long-term fluctuations of runoff in southern Kazakhstan. In our opinion, the short and sometimes distorted records of monthly discharge data should be exercised cautiously in water balance modeling and runoff projections for water resource management. Future water balance modeling should combine the discharge and climatic proxies with the instrumental data. The impact of cold-season precipitation on runoff to internal basins of Central Asia requires further studied and better measurements. In the context of warming, the changing contribution of glacial meltwater to river is also a critical subject for further research.

\section{Reference List}

Abdolvand et al. (2015) The dimension of water in Central Asia: security concerns and the long road of capacity building. Envir Earth Sci 73(2): 897-912.

Agafonov LI, Meko DM, Panyushkina IP (2016) Reconstruction of Ob River, Russia, from ring widths of floodplain trees. J Hydrology 543: 198-217. 
Aizen VB, Aizen EM, Melack JM (1996) Precipitation, melt and runoff in the northern Tien Shan. J Hydrology 186: 229-251.

Aizen, VB, Aizen AM, Melack JM, Dozier J (1997) Climatic and hydrologic changes in the Tien Shan, Central Asia. J Am Meteor Soc 10: 1393-1404.

Barnston AG, Livezey RE (1987) Classification, Seasonality and Persistence of LowFrequency Atmospheric Circulation Patterns. Monthly Weath Rev 115 (6): 1083-1126.

Bernauer T, Siegfried T (2008) Compliance and Performance in International Water Agreements: The Case of the Naryn/Syr Darya Basin. Global Governance 14: 479-501.

Blackman RB, Tukey JW (1958) The Measurement of Power Spectra from the Point of View of Communication Engineering. Dover Publ, New York.

Bloomfield P (2000) Fourier Analysis of Time Series: An Introduction. John Wiley \& Sons, New York.

Bodo BA (2000) Monthly Discharges for 2400 Rivers and Streams of the former Soviet Union. Canada.

Borscheva NM (1986) Impact of biological and climatic factors on radial growth of Schrenk's spruce. In: Dendrochronology and Dendroclimatology, LA Kairiukstis GI Galazy, SG Shiyatov (eds.), Novosibirsk, Nauka, 71- 76.

Borscheva NM (1988) Limiting factors of Schrenk's spruce radial growth. In: Ecological Studies in Northern Kirgizstan. Tian Shan Mountain Research Station Press. Frunze, pp 15-22.

Bothe O, Fraedrich K, Zhu X (2012) Precipitation climate of Central Asia and the largescale atmospheric circulation. Theoretical and Applied Climatology 108 (3-4): 345-354.

Buckley BM et al. (2010) Climate as a contributing factor in the demise of Angkor, Cambodia. PNAS 107: 6748-6752 doi: 10.1073/ pnas.0910827107.

Cook ER, Peters K (1981) The smoothing spline: a new approach to standardizing forest interior tree-ring width series for dendroclimatic studies. Tree-Ring Bull 41: 45-53.

Cook ER, Krusic PJ, Holmes RH, Peters K (2007) Program ARSTAN, Version 41d, download from www.ldeo.columbia.edu/tree-ring-laboratory.

Chen F, He Q, Ermenbaev B, Yu S-L, Zhang R (2015) Climatic signals in tree rings of Juniperus turkestanica in the Gulcha River Basin (Kyrgyzstan) reveals the recent wetting trend of high Asia. Dendrobiology 74: 33-40.

Chen F, Yuan Y, Davi N, Zhang T (2016) Upper Irtysh River flow since AD 1500 as 
reconstructed by tree rings, reveals the hydroclimatic signal of inner Asia. Clim Change 139, doi:10.1007/s10584-016-1814-y

Chen F, Yu S (2017a) Tree-ring indicators of rainfall and streamflow for the IliBalkhash Basin, Central Asia since CE 1560. Paleogeo Paleoclim Paleocolo 482 (15): 48-56.

Chen F, He Q, bakytbek E, Yu S, Zhang R (2017b) Reconstruction of along streamflow record using tree rings in the upper Kurshab River (Pamir-Alai Mountains) and its application to water resources management. Int J Water Res Development 33(2): 997-986.

Cohen J, Saito K, Entekhabi D (2001) The role of the Siberian High in Northern Hemisphere climate variability. Geophys Res Lett 28: 299-302.

Compo et al (2011) The Twentieth Century Reanalysis Project. Quarterly J Royal Meteorol Soc 137: 1-28, doi: 10.1002/qj.776.

Endo K et al. (2012) Lake level change and environmental evolution during the last 8000 years from the Balkhash Lake cores in Central Eurasia. In: Towards Sustainable Society in Central Asia: Historical Perspective on the Future. RIHN, Kyoto, pp 77-92.

D'Arrigo R, Jacoby GJ, Wilson R, Panagiotopoulos F (2005) A reconstructed Siberian High index since A.D. 1599 from Eurasian and North American tree rings. Geoph Res Lett 32: L05705.

Fang K, Davi N, Gou X, Chen F, Cook ER, Li J, D’Arrigo R (2010) Spatial drought reconstructions for central High Asia based on tree rings. Clim Dynam 35(6): 941-951.

Farinotti D, Longuevergne L, Moholdt G, Duethmann D, Molg T, Bolch T, Vorogushyn S, Gunter A (2015) Substantial glacier mass loss in the Tien Shan over the past 50 years. Nature Geoscience 8, 716-722, doi:10.1038/ngeo2513

Fritts HC, Guiot J, Gordon GA (1990) Verification. ER Cook and LA Kairiukstis (eds.) Methods of Dendrochronology: applications in the environmental sciences. Kluwer Academic Publ, Dordrecht, the Netherlands, 78-85.

Grinsted A, Moore AJ, Jevrejeva S (2004) Application of the cross wavelet transform and wavelet coherence to geophysical time series. Nonlinear Process: Geophys 11: 561-566.

Goulden ML, Anderson RG, Bales RC, Kelly AE, Meadows M, Winston GC (2012) Evapotranspiration along an elevation gradient in California's Sierra Nevada. J Geophys Res 117: G03028, doi:10.1029/2012JG002027.

Hsiang SM, Burke M, Miguel E (2013) Quantifying the influence of climate on human conflict. Science 341(6151):1235367. 
Holmes (1983) Computer-assisted quality control in tree-ring dating and measurement. Tree Ring Bull 43:69-78.

Jeong J-H, Ou T, Linderholm HW, Kim B-M, Kim S-J, Kug J-S, Chen D (2011) Recent recovery of the Siberian High intensity. J Geophys Res 116: D23102.

Jhun J-G, Lee E-J (2004) A new East Asian winter monsoon index and associated characteristics of the winter monsoon, J. Clim 17: 711- 726.

Jolliffe IT (2002) Principal Component Analysis. Springer Series in Statistics, $2^{\text {nd }}$ edn. Springer, New York.

Kelley CP, Mohtadi S, Cane MA, Seager R, Kushnir Y (2015) Climate change in the Fertile Crescent and implications of the recent Syrian drought. PNAS, 112 (11): 2413246, doi/10.1073/pnas.1421533112

Konovalov VG, Maksimova OE (2012) Reconstruction and forecast of water balance in the Naryn River from tree rings. Snow and Ice J 3 (119): 87-98.

Konovalov VG, Pimankina NV (2016) Spatial-temporal variability of water balance components in the north of Zailiisky Alatau Range. Ice and Snow J 56(4): 453-471.

Kozhevnikova ND (1982) Biology and Ecology of Tien-Shan Spruce. ILIM, Frunze.

Kozhevnikova ND (1986) Response of Schrenk’s spruce morphology to tree age. In: Dendrochronology and Dendroclimatology, LA Kairiukstis GI Galazy, SG Shiyatov (eds.), Novosibirsk, Nauka, 68-121.

Kuzmichenok V (2009) Monitoring of water, snow and glacial resources of Kyrgyzstan. Assessment of Snow, Glacier and Water Resources in Asia 8: 84-99.

Lammers RB, Shiklomanov AI, Vorosmarty CJ, Fekete BM, Peterson BJ (2001) Assessment of contemporary Arctic river runoff based on observational discharge records, J. Geophys. Res., 106 (D4), 3321-3334.

Li J, Gou X, Cook ER, Chen F (2006) Tree-ring based drought reconstruction for the central Tien Shan area in northwest China. Geoph Res Let 33(7),

doi: 10.1029/2006GL025803.

Lydolf PE (1977) Climates of the Soviet Union. Elsevier, Oxford.

Macklin MG, Panyushkina IP et al. (2015) The influence of Late Pleistocene geomorphological inheritance and Holocene hydromorphic regimes on floodwater farming in the Talgar catchment, southeast Kazakhstan, Central Asia. Qua Sci Rev 129: 85-95.

Mallows CL (1973) Some comments on cp. Technometrics 15: 661-675. 
Mamatkanov DM et al. (2006) Water Resources of Kyrgyzstan. NASK, Water Problems and Hydropower, Bishkek.

Meko DM, Therrell MD, Baisan CH, Hughes MK (2001) Sacramento River flow reconstructed to A.D. 869 from tree rings. J Am Water Res Ass 37 (4): 1029-1040.

Meko DM, Touchan R, Anchukaitis KA (2011) Seascorr: a MATLAB program for identifying the seasonal climate signal in an annual tree-ring time series. Comp \& Geoscie 37: 1234-1241.

Meko DM, Woodhouse CA (2011) Application of streamflow reconstruction to water resources management. In: MK Hughes et al. (eds) Dendroclimatology. Progress and Prospects, Developments in Paleoenvironmental Research 11, Springer, pp 231-261.

Michaelsen J (1987) Cross-validation in statistical climate forecast models. J Clim Appl Meteor 26: 1589-1600.

Osborn TJ, Briffa KR, Jones PD (1997) Adjusting variance for sample-size in tree-ring chronologies and other regional mean time series. Dendrochronologia 15: 89-99.

Panagiotopoulos F, Shahgedanova M, Hannachi A, Stephenson D (2005) Observed trends and teleconnections of the Siberian High. J Climate 18: 1411-1422.

Pederson et al (2013) Three centuries of shifting hydroclimatic regimes across the Mongolian Breadbasket. Agr and Forest Meteor 178: 10-20.

Siegfried T, Bernauer T, Guiennet R, Sellars RS, Robertson A, Mankin J, BauerGottwein, Yakovlev A (2011) Will climate change exacerbate water stress in Central Asia? Climatic Change, DOI 10.1007/s10584-011-0253-z.

Siegfried T and Bernauer T (2015) Climate Change and international water conflict in Central Asia. J Peace Res 49(1): 227-239.

Shiklomanov et al. (2013) Hydrological Changes: Historical Analysis, Contemporary Status, and Future Projections. In: PY Groisman, G Gutman (eds.) Regional Environmental Changes in Siberia and Their Global Consequences. Springer, Envir Scie and Engineer

Shiyatov SG, Mazepa V, Cook E (1990) Correcting for trend in variance due to changing sample size. In: ER Cook and LA Kairiukstis (eds.) Methods of Dendrochronology: applications in the environmental sciences. Kluwer Academic Publ., Dordrecht, the Netherlands, 133-152.

Solomina ON, Maksimova OE (2010) Dendroclimatic studies in the Tian Shan Mountains as the source of climate variability. Proc of RAS Geogr Ser 6: 54-66. 
Sorg A, Bolch T, Stoffel M, Solomina O, Beniston M (2012) Climate change impacts on glaciers and runoff in Tien Shan (Central Asia). Nature Climate Change, doi:

10.1038/nclimate1592.

Stokes MA, Smiley M (1968) An Introduction to Tree-ring Dating. U of Chicago Press, Chicago.

Takeuchi N et al (2014) The disappearance of glaciers in the Tien Shan Mountains in Central Asia at the end of Pleistocene. Quat Sci Rev 103: 26-33.

Torrence C, Compo GP (1998) A Practical Guide to Wavelet Analysis. Bull Amer Meteor Soc 79: 61-78.

Touchan R, Kherchouche D, Oudjehih B, Touchan H, Slimani S, Meko DM (2016) Dendroclimatology and wheat production in Algeria.

-A1Pid Env ir $124: 102$

Vilesov EN, Uvarov VN (2001) Evolution of Glaciation in the Zailiyskiy Alatau during the 20th Century. Kazakh State Unv, Almaty.

Wang T, Ren H, Ma K (2005) Climatic signals in tree ring of Picea schrenkiana along an altitudinal gradient in the central Tian-Shan Mountains, northwestern China. Trees 19: 735-741.

Weisberg S (1985) Applied Linear Regression, $2^{\text {nd }}$ edn, John Wiley, New York.

Wells N, Goddard S., Hayes M (2004) A self-calibrated Palmer Drought Severity Index. Am Meteor Soc J 17: 2335-2351.

Wigley TML, Briffa KR, Jones PD (1984) On the average value of correlated time series, with applications in dendroclimatology and hydrometeorology. Clim Appl Meteor 23: 201-213.

Woodhouse CA, Gray ST, Meko DM (2006) Updated streamflow reconstructions for the Upper Colorado River Basin. Wat Resou Res 42 (W05415), doi: 10.1029/2005WR004,455

Wu B, Wang J (2002) Winter Arctic Oscillation, Siberian High and east Asian winter monsoon, Geophys Res Lett 29(19): 1897, doi:10.1029/2002GL015373.

Yuan Y, Shao X, Wei W, Yu S, Gong Y, Trouet V (2007) The potential to reconstruct Manasi River streamflow in the Northern Tien Shan Mountains (NW China). Tree-Ring Res 63(2): 81-93.

Zhang D, Brecke P, Lee HF, He YO, Zhang J (2007) Global climate change, war, and population decline in recent human history. PNAS, 19214-19219, doi:

10.1073/pnas.0703073104. 
Zhang RB et al (2016) Streamflow variability for the Aksu River on the southern slopes of the Tian Shan inferred from tree ring records. Quat Res, doi:

10.1016/j.yqres.2016.03.001.

Zhang et al (2017a) A 189-year tree-ring record of drought for the Dzungarian Alatau, arid Central Asia. J Asian Earth Science 148:305-314.

Zhang R, Shang H, Yu S, He Q, Yuan Y, Bolatov K, Mambetov BT (2017b) Tree- ringbased precipitation reconstruction in southern Kazakhstan, reveals drought variability since A.D. 1770. Int J Climatol 37 (2): 741-750.

Zhou H, Aizen E, Aizen V (2017) Constructing a long-term monthly climate data set in central Asia. Int J Climatology, DOI: 10.1002/joc.5259 


\section{Figures and Captions}

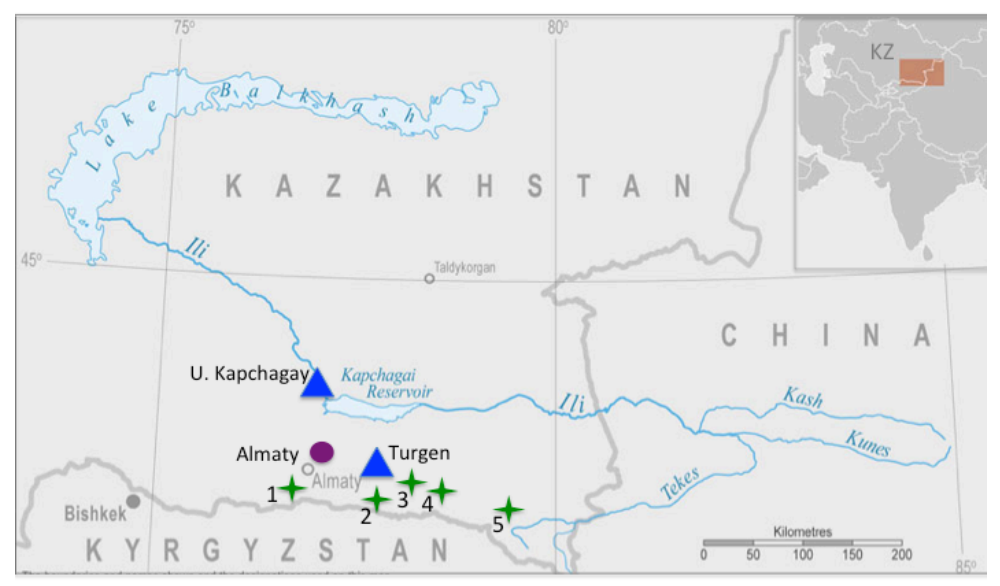

Figure 1. Map of study area and data locations. Circle marks Almaty weather station. Triangles mark stream gauges (Table 3). Stars mark tree-ring chronology locations in the Zailiyskiy Alatau Range of the Tian Shan Mountains: (1), Assy (2), Essyk (3), Turgen (4) and Chilik (5).

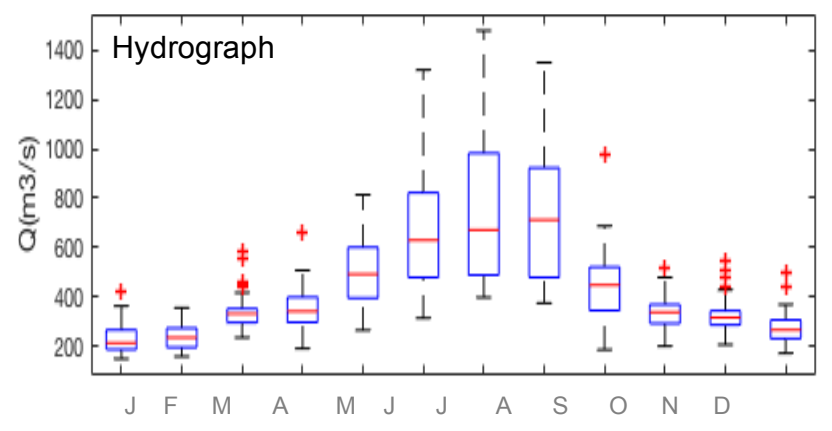

Figure 2. Monthly hydrograph of Ili River discharge as recorded at U. Kapchagay gauge. Gauge is at elevation $428 \mathrm{~m}$ asl and analyzed period is 1936-1985. Discharge in individual months is displayed as box plots with a horizontal line at the median, a box over the interquartile range, and plus signs at values more than 1.5 times the interquartile range above or below the box. If there are no such outliers, the bracket marks the data extremes. 


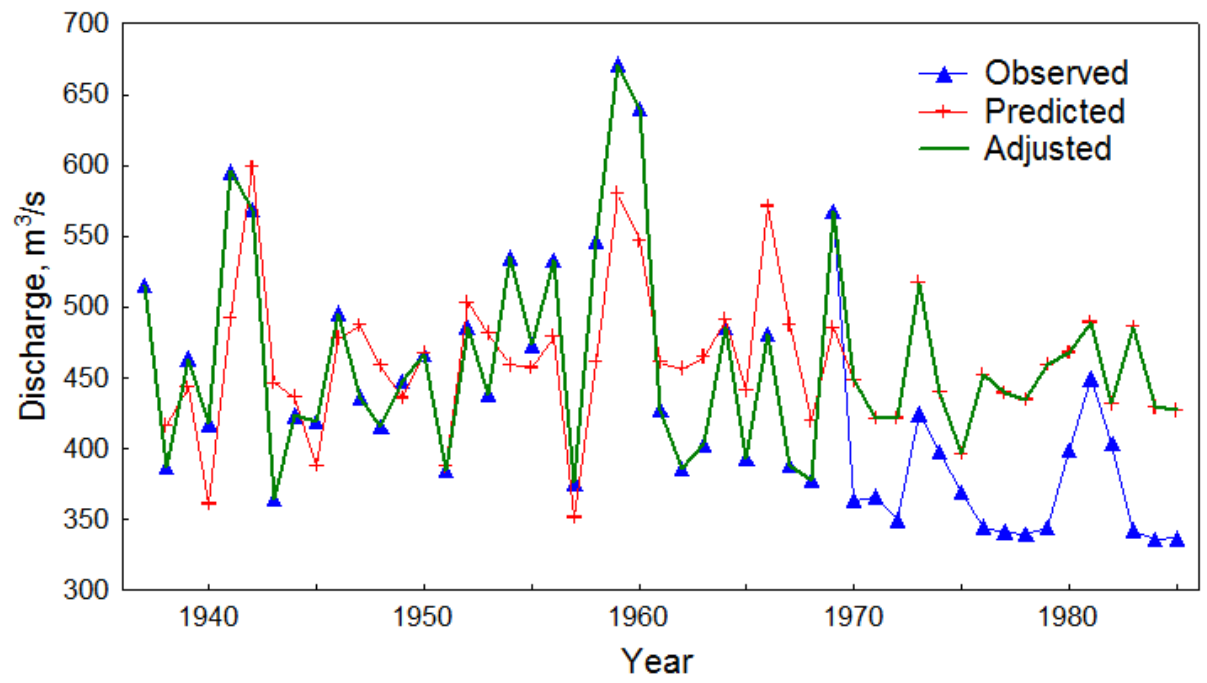

Figure 3. Time plots illustrating adjustment of annual discharge record for gauge U. Kapchagay. Shown are plots of the original measurements, predictions from regression using records for gauge Turgen (see text), and the adjusted record, which uses the predictions for the period after the flows at U. Kapchagay are distorted by reservoir operation. Mean for unadjusted series is $Q=434 \mathrm{~m}^{3} / \mathrm{s}$ (Std. Dev. 82.3). Mean for adjusted series is $\mathrm{Q}=460 \mathrm{~m}^{3} / \mathrm{s}$ (Std. Dev. 68.1). 


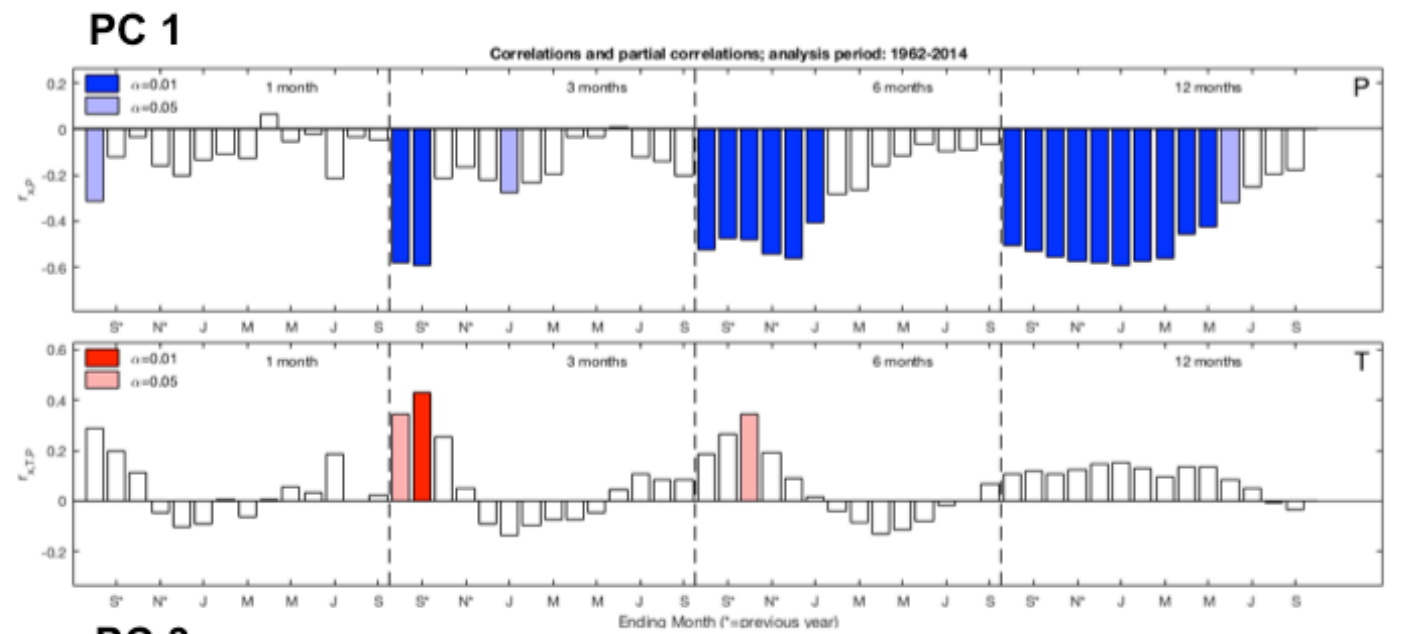

\section{PC 3}

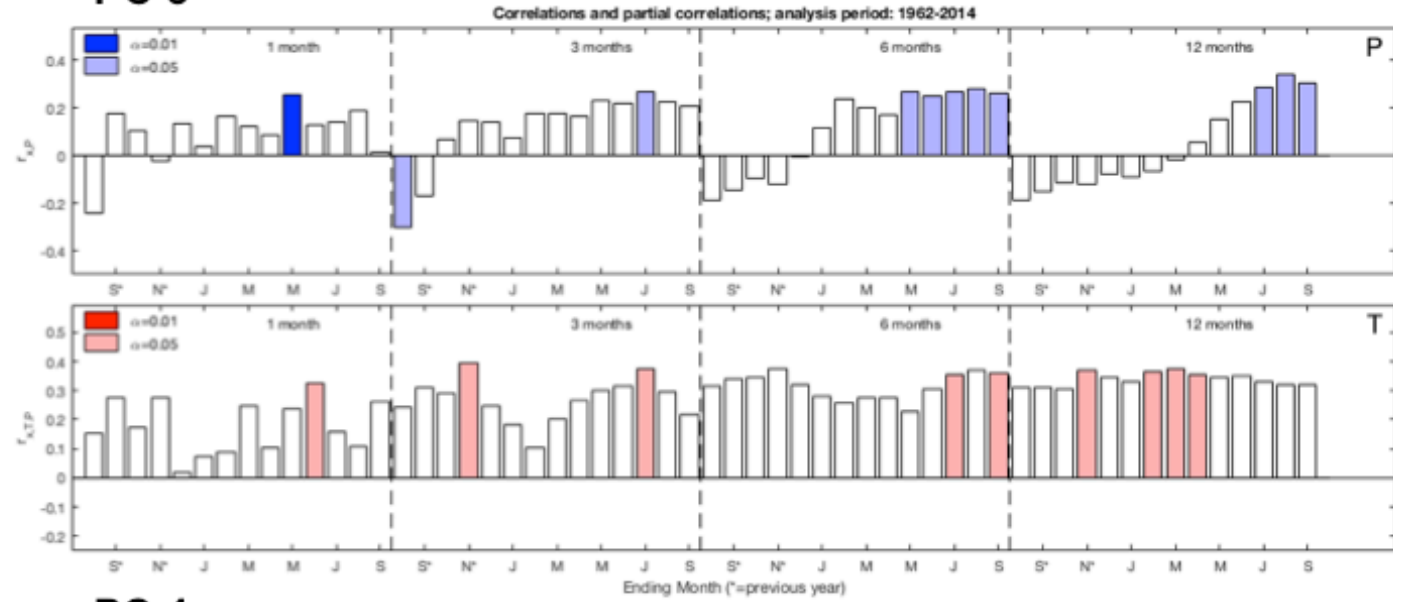

PC 4

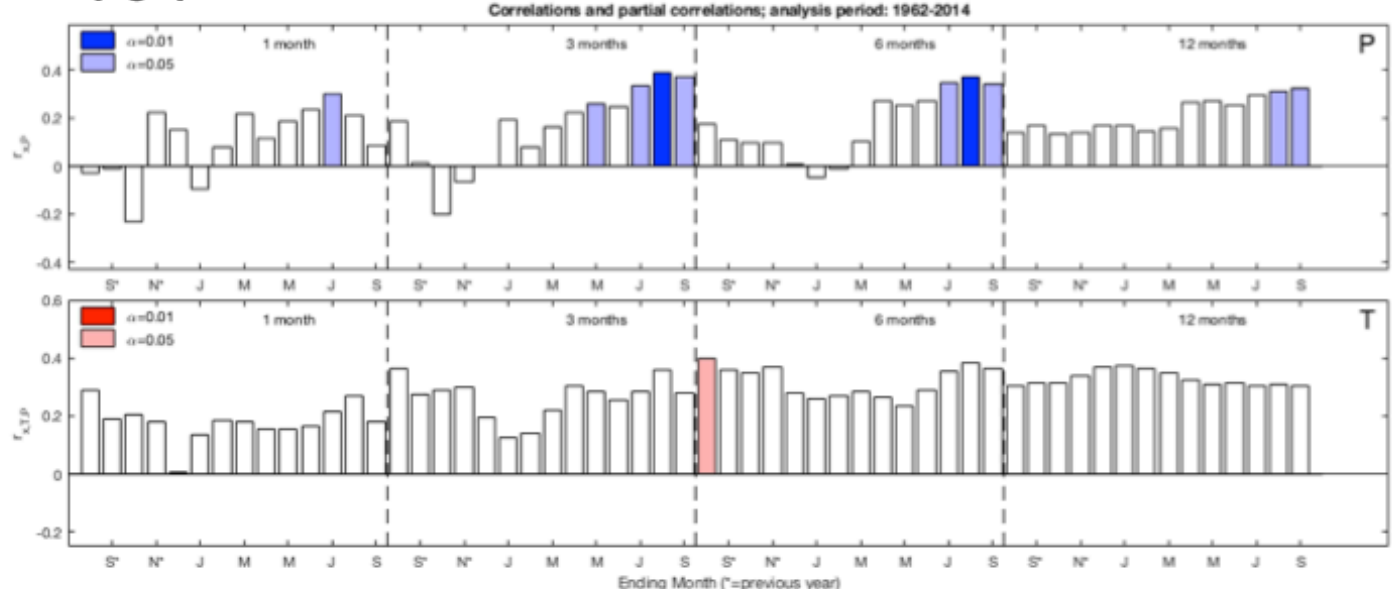

Figure 4. Monthly and seasonal correlations of PC1, PC3 and PC4 with climate data of Almaty station for period 1960-2014. Top plot for each output from program Seascorr shows primary correlations (P, blue bars) and the bottom plot - partial correlations ( $\mathrm{T}$, red bars). Results shown for season length of 1, 3, 6 and 12 months with variable ending 
month. Significance estimated by Monte Carlo method (Meko et al. 2011) is colorvariance coded for two $\alpha$ levels. Seascorr results not shown for tree-ring PCs not used in discharge reconstruction model (i.e., those that do not enter the stepwise regression).

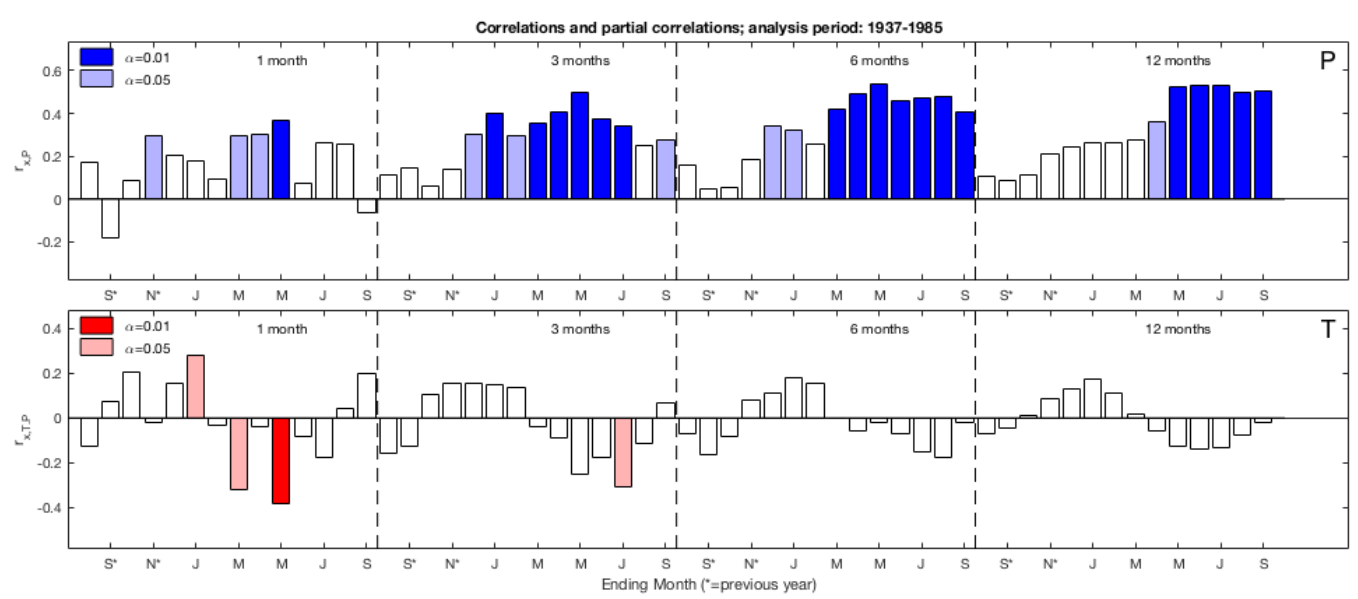

Figure 5. Monthly and seasonal correlations of Ili River annual discharge at U. Kapchagay gauge with climate data for Almaty, 1937-1985. Output from program Seascorr shows primary correlations with precipitation (Top, blue bars) and partial correlations with temperature (Bottom, red bars). Results shown for seasons of length 1, 3, 6 and 12 months with variable ending months. Significance, estimated by Monte Carlo simulation (Meko et al. 2011), is color-variance coded for two $\alpha$ levels.

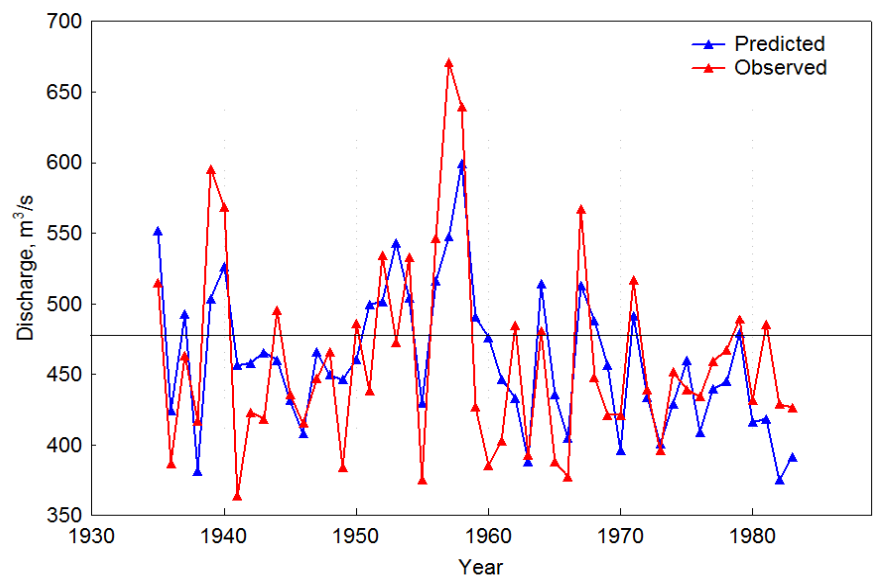

Figure 6. Observed and predicted discharge of the Ili River for 1937-1985 calibration period of reconstruction model. Horizontal line is calibration-period mean, $460 \mathrm{~m}^{3} / \mathrm{s}$. Red line is gauged discharge and blue line is predicted. 


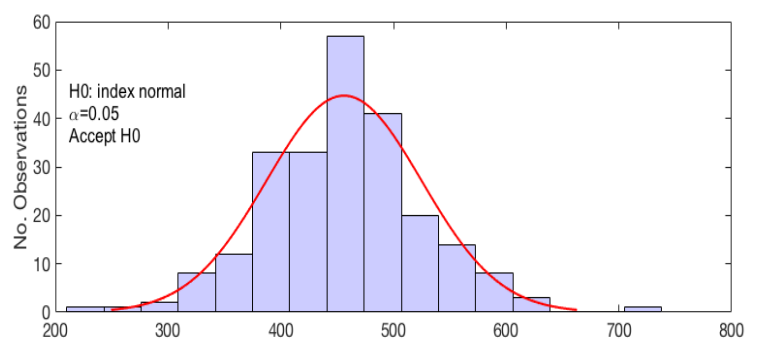

Figure 7. Histogram of reconstructed discharge, 1779-2015. Positive result of Lilliefors test for normality is annotated at upper left.

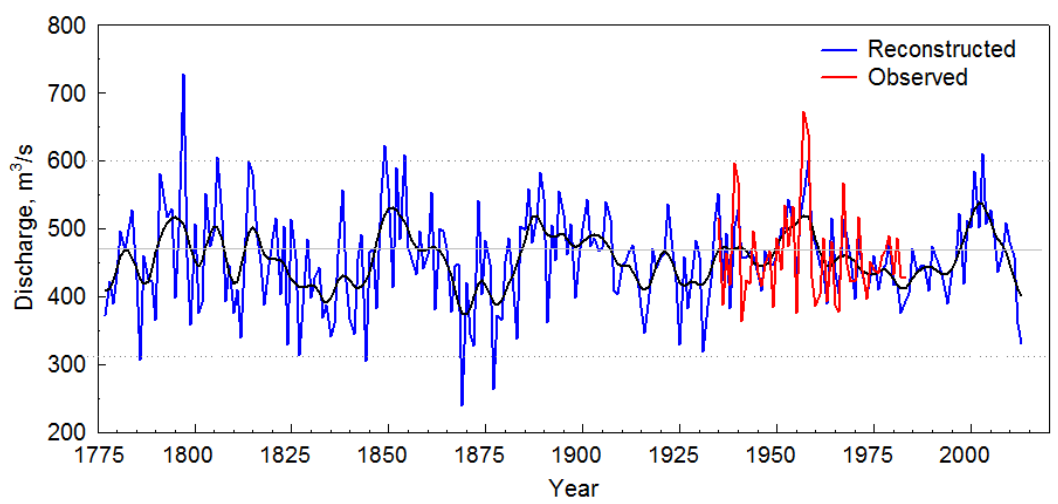

Figure 8. Reconstructed Oct-Sept discharge of the Ili River at U. Kapchagay, 1779-2015. Red line is instrumental discharge. Black line emphasizes decadal variations estimated with 10-year Tukey filter. Horizontal grey line is at $460 \mathrm{~m}^{3} / \mathrm{s}$ calibration-period mean (1937-1985). Grey dash lines at $+2 \sigma\left(594 \mathrm{~m}^{3} / \mathrm{s}\right)$ and $-2 \sigma\left(316 \mathrm{~m}^{3} / \mathrm{s}\right)$ delineate discharge extremes.

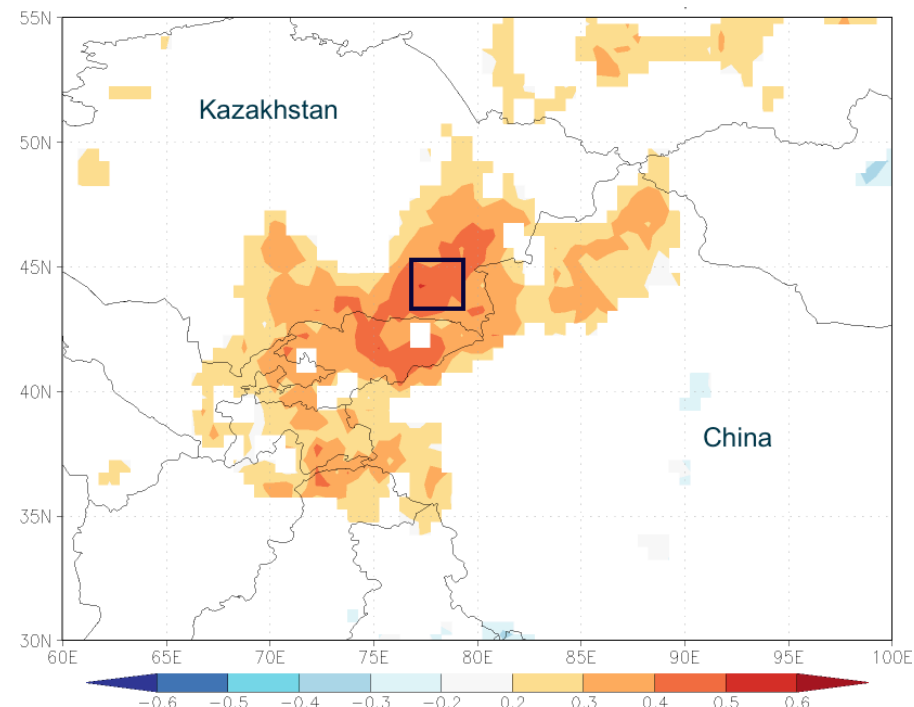


Figure 9. Spatial correlation of reconstructed Oct-Sept discharge of Ili River with gridded Oct-Sept scPDSI field (CRU 3.24) for interval 1901-2014 ( $\left.\mathrm{p}_{\text {field }}<0.5\right)$. Rectangle shows the location of tree-ring sites.

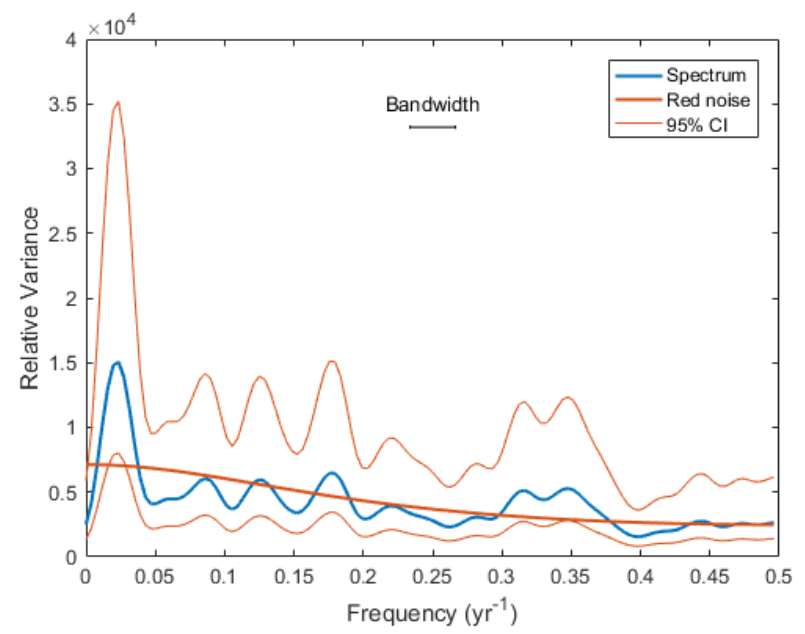

Figure 10. Spectrum of reconstructed discharge of Ili River, 1779-2012. Significant spectral peak relative to red noise is at 42.7 years. Spectrum estimated by smoothedperiodogram method (Bloomfield 2000). Raw periodogram smoothed with three Daniell filters with spans 3, 5 and 7 to produce plotted spectrum.

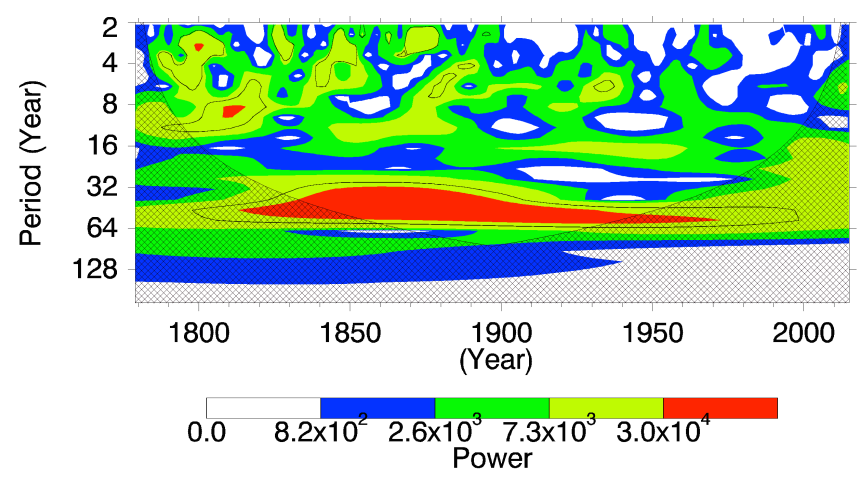

Figure 11. The wavelet power spectrum (Morlet 6.0/6) of the reconstructed Oct-Set discharge of Ili River for period 1779-2015. Contour levels chosen so that 75\%, 50\%, $25 \%$, and $5 \%$ of the wavelet power is above each level, respectively. The cross-hatched region is the cone of influence, where zero padding has reduced the variance. Black contour is the $10 \%$ significance level, using a red-noise (autoregressive lag1) background spectrum. 

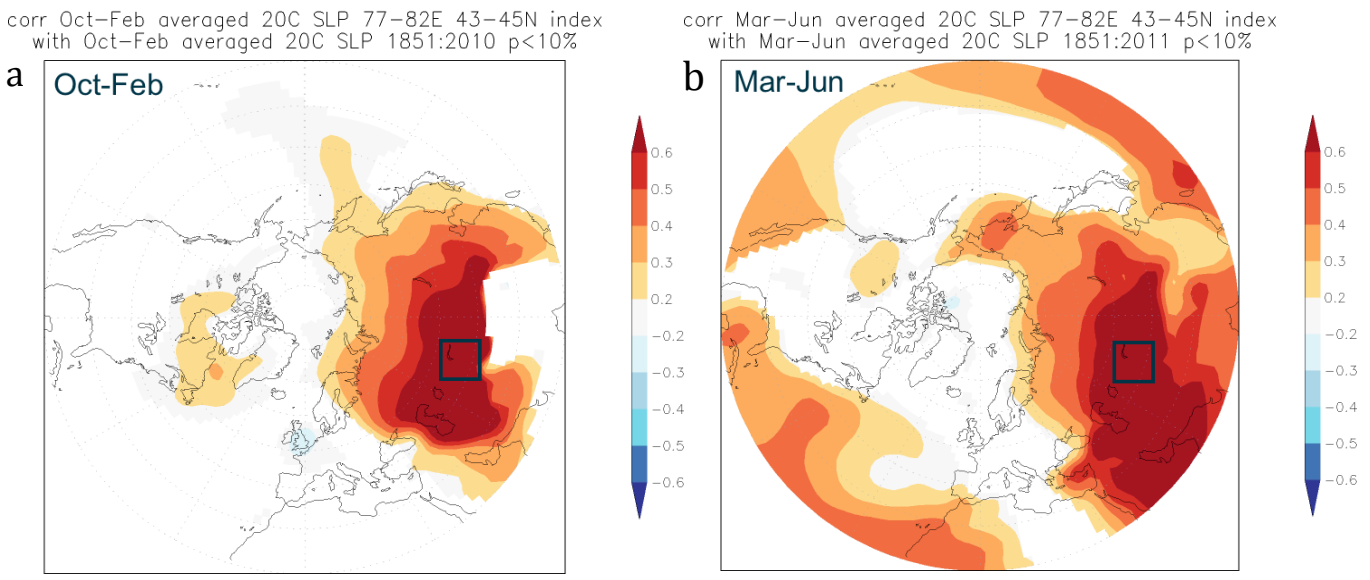

Figure 12. Correlation fields between the surface pressure (SLP) over the Ili River basin and the northern hemisphere calculated with the 20th Century Reanalysis data for interval 1851-2010: a) October-February period of snow pack accumulation, and b) March-June period of spring precipitation. Rectangle marks study basin. Scale of correlation is at right.

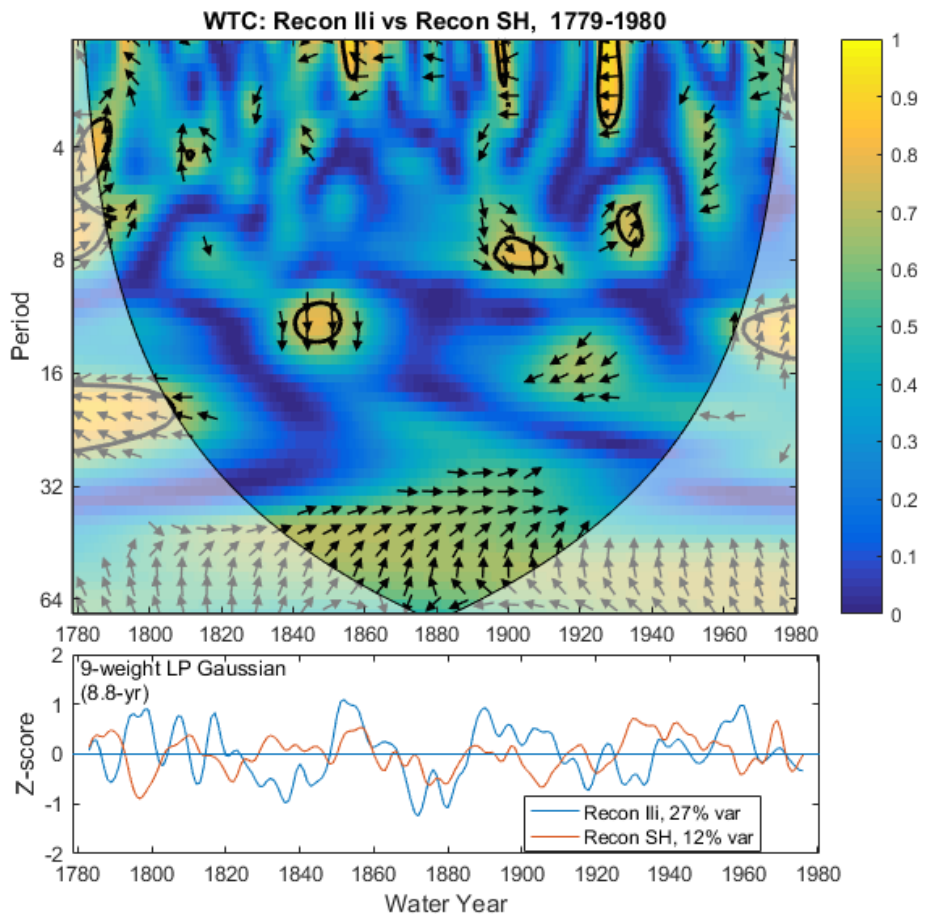

Figure 13. Wavelet transform coherency for reconstructed Ili discharge (this study) and reconstructed Siberian High Index (D'Arrigo et al. 2005), 1779-1980. Yellow enclosed 
by black line is high coherency significant at $\alpha=0.05$ by Monte Carlo testing. Direction of arrows indicates phase. Series in phase have arrows pointing to right; series $180^{\circ}$ out of phase (e.g., peaks in one occur with troughs in the other) have arrows to left. Z-score plot at bottom is for the time series converted to zero mean and unit variance smoothed by Gaussian filter (a 9-weight filter with 50\% frequency response at wavelength $8.8 \mathrm{yr}$ ) to emphasize decadal-and-longer periods. The inverted cone marks areas of risky interpretation due distortion from end-effects.

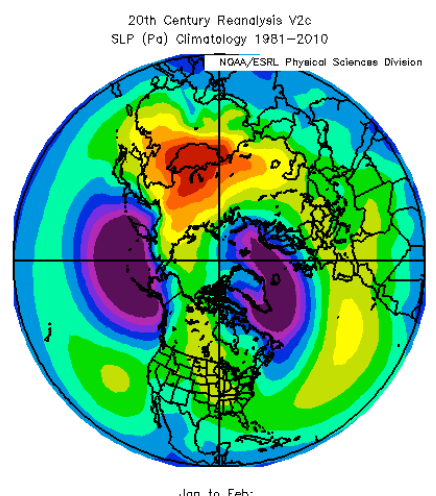

$\mathrm{b}$

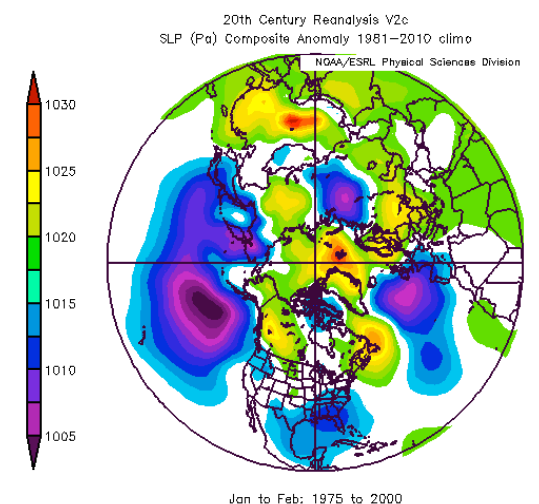

$\mathrm{C}$

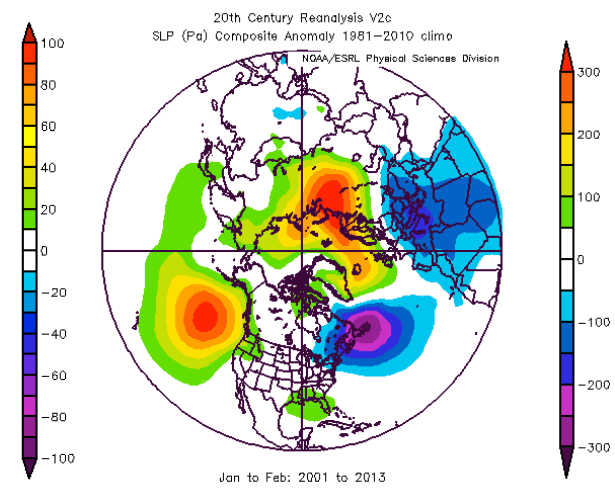

Figure 14. Composite maps of the 20th Century Reanalysis data of Jan-Feb surface pressure for a) normal condition for interval 1981-2010, b) anomaly during reconstructed low-flow interval of 1975-2000, and c) anomaly during reconstructed high-flow interval of 2001-2013. 


\section{Tables}

Table 1. Site coordinates and statistics for 11 tree-ring chronologies.

\begin{tabular}{|c|c|c|c|c|c|c|c|c|}
\hline $\begin{array}{c}\text { Site } \\
\text { ID }\end{array}$ & $\begin{array}{c}{ }^{1} \text { Coordi- } \\
\text { nates }\end{array}$ & Location & $\begin{array}{c}\text { Eleva- } \\
\text { tion, } \\
\mathrm{m} \text { asl }\end{array}$ & $\begin{array}{c}\text { Span \& } \\
\text { Length, yrs }\end{array}$ & $\begin{array}{l}\# \\
\text { Series }\end{array}$ & ${ }^{2}$ EPS & $\begin{array}{l}\text { Std. } \\
\text { Dev. }\end{array}$ & ${ }^{3} A R$ \\
\hline GOR & $\begin{array}{l}\text { N 43.13480 } \\
\text { E 77.50102 }\end{array}$ & M.Almatinka & 2000 & $\begin{array}{c}1980-2015 \\
126\end{array}$ & 20 & 1910 & 0.17 & 0.34 \\
\hline BAO & $\begin{array}{l}\text { N } 43.13496 \\
\text { E } 77.50188\end{array}$ & M.Almatinka & 2200 & $\begin{array}{c}1779-2010 \\
232\end{array}$ & 17 & 1818 & 0.16 & 0.28 \\
\hline TK & $\begin{array}{l}\text { N } 43.14454 \\
\text { E } 77.11021\end{array}$ & Assy & 2600 & $\begin{array}{c}1779-2015 \\
237\end{array}$ & 29 & 1843 & 0.22 & 0.44 \\
\hline TER & $\begin{array}{l}\text { N } 43.14350 \\
\text { E } 77.17760\end{array}$ & Assy & 2400 & $\begin{array}{c}1704-2011 \\
308\end{array}$ & 23 & 1839 & 0.29 & 0.38 \\
\hline OJ2 & $\begin{array}{l}\text { N } 43.13290 \\
\text { E } 77.49301\end{array}$ & Turgen & 2400 & $\begin{array}{c}1693-2015 \\
323\end{array}$ & 25 & 1775 & 0.29 & 0.38 \\
\hline ORM & $\begin{array}{l}\text { N } 43.16340 \\
\text { E } 77.44101\end{array}$ & Turgen & 2700 & $\begin{array}{c}1885-2001 \\
117\end{array}$ & 24 & 1902 & 0.17 & 0.27 \\
\hline E2 & $\begin{array}{l}\text { N } 43.15130 \\
\text { E 77.27759 }\end{array}$ & Essyk & 1700 & $\begin{array}{c}1925-2011 \\
87\end{array}$ & 25 & 1937 & 0.17 & 0.15 \\
\hline MAR & $\begin{array}{l}\mathrm{N} 43.58843 \\
\text { E } 77.19086\end{array}$ & Essyk & 1800 & $\begin{array}{c}1874-2015 \\
142\end{array}$ & 26 & 1891 & 01.6 & 0.19 \\
\hline AKBK & $\begin{array}{l}\text { N } 43.15728 \\
\text { E 77.24181 }\end{array}$ & Essyk & 1900 & $\begin{array}{c}1768-2016 \\
249\end{array}$ & 17 & 1803 & 0.19 & 0.37 \\
\hline NG & $\begin{array}{l}\mathrm{N} 42.58576 \\
\mathrm{E} 78.21925\end{array}$ & Chilik & 2000 & $\begin{array}{c}1816-2015 \\
200\end{array}$ & 26 & 1869 & 0.17 & 0.45 \\
\hline KOL & $\begin{array}{l}\text { N } 42.59477 \\
\text { E 78.19543 }\end{array}$ & Chilik & 1800 & $\begin{array}{c}1761-2015 \\
255\end{array}$ & 38 & 1783 & 0.20 & 0.33 \\
\hline
\end{tabular}

${ }^{1}$ Decimal coordinates of latitude and longitude. ${ }^{2}$ First year EPS $>0.85,{ }^{3}$ Auto correlation coefficient at lag 1 .

Table 2. Statistics of composite ring-width chronologies. These 5 chronologies were formed from subsets of the 11 chronologies listed in Table 1 (see text).

\begin{tabular}{lcccccccc}
\hline$\#$ & $\begin{array}{c}\text { Chronology } \\
\text { Location }\end{array}$ & $\begin{array}{c}\text { Elevation, } \\
\text { m asl }\end{array}$ & Span & Length & $\begin{array}{c}\text { Number } \\
\text { series }\end{array}$ & ${ }^{1}$ EPS & $\begin{array}{c}\text { Std. } \\
\text { Dev. }\end{array}$ & ${ }^{2}$ AR \\
\hline 1 & Assy & $2400-2600$ & $1704-2015$ & 312 & 50 & 1835 & 0.24 & 0.31 \\
2 & Turgen & $2400-2700$ & $1693-2015$ & 323 & 39 & 1823 & 0.26 & 0.31 \\
3 & M. Almatinka & $2000-2200$ & $1779-2015$ & 237 & 35 & 1818 & 0.15 & 0.33 \\
4 & Chilik & $1800-2000$ & $1761-2015$ & 255 & 64 & 1779 & 0.17 & 0.50 \\
5 & Essyk & $1700-1900$ & $1768-2016$ & 248 & 62 & 1803 & 0.18 & 0.36 \\
& & & & & & & \\
\hline
\end{tabular}

${ }^{1}$ EPS- First year at EPS $>0.85,5-6$ trees, ${ }^{2}$ AR- Autocorrelation coefficient at lag 1. 
Table 3. Factor loadings of principal components from PCA of the tree-ring chronologies. PCA was run on the correlation matrix 1779-2015. Percentages of variance described are as follows: $52.1 \%$ (Factor 1), 19.5\% (Factor 2), 12.5\% (Factor 3 ) and 9.5\% (Factor 4).

\begin{tabular}{|c|c|c|c|c|}
\hline Chronology & $\begin{array}{c}\text { Factor } \\
1\end{array}$ & $\begin{array}{c}\text { Factor } \\
2\end{array}$ & $\begin{array}{c}\text { Factor } \\
3\end{array}$ & $\begin{array}{c}\text { Factor } \\
4\end{array}$ \\
\hline Assy & 0.504 & -0.149 & -0.517 & 0.114 \\
\hline Turgen & 0.489 & 0.199 & 0.238 & 0.768 \\
\hline M. Almatinka & 0.195 & -0.934 & 0.255 & -0.016 \\
\hline Chilik & 0.509 & 0.103 & -0.411 & -0.439 \\
\hline Essyk & 0.457 & 0.234 & 0.665 & -0.452 \\
\hline
\end{tabular}

Table 4. Calibration and validation statistics ${ }^{1}$ of stepwise regression for reconstruction model of Ili River annual discharge. Calibration period is 1937-1985 (49 years). Step 3 has the statistics for the final model used for reconstruction. See text and equation 2 for model equation and estimated coefficients.

\begin{tabular}{llccccccc}
\hline Step & Predictors & $\boldsymbol{R}$ & $\boldsymbol{R}^{\mathbf{2}}$ & $\begin{array}{c}\boldsymbol{R}^{\mathbf{2}} \\
\boldsymbol{a d j .}\end{array}$ & $\begin{array}{c}\text { Mallow } \\
\boldsymbol{s} \boldsymbol{C}_{\boldsymbol{p}}\end{array}$ & $\boldsymbol{p D W}$ & PRESS & $\boldsymbol{R}^{\mathbf{2}}$ pred. \\
\hline $\mathbf{1}$ & $P C 3$ & 0.59 & 0.35 & 0.33 & 17.4 & 1.85 & 0.159 & 0.28 \\
$\mathbf{2}$ & $P C 3, P C 1$ & 0.68 & 0.46 & 0.44 & 8.0 & 1.76 & 0.135 & 0.39 \\
$\mathbf{3}$ & $P C 3, P C 1, P C 4$ & 0.73 & 0.53 & 0.50 & 3.8 & 1.69 & 0.123 & 0.45 \\
\hline
\end{tabular}

${ }^{1} R^{-}$correlation, $R^{2}$ - $R$-square, $R^{2}$ adj-adjusted $R$-square, Mallows $C_{p}, p D W$ - $p$ value of Durbin-Watson statistic, PRESS statisticR ${ }^{2}$ predicted.

Table 5. Statistics of gauged and tree-ring reconstructed discharge $\left(\mathrm{m}^{3} / \mathrm{s}\right)$ of Ili River at U. Kapchagay.

\begin{tabular}{llllll}
\hline Variable & Interval & Mean & Minimum & Maximum & Std. Dev. \\
\hline Observed & $1937-1985(49)$ & 460.39 & 364 & 671.25 & 67.91 \\
Predicted & $1779-2015(237)$ & 455.07 & 238.89 & 727.93 & 69.18 \\
\hline
\end{tabular}


Table 6. Correlation of reconstructed and gauged discharge of Ili River (Q) with climatic indices. ${ }^{1}$ Climatic indices are averages for winter (Oct-Feb) and spring (Mar-Jun). Only significant correlations are listed: $\mathrm{p}<0.05$ or $\mathrm{p}<0.07-0.09$ if marked with *. Analysis period 1950-1985 (36 yrs).

\begin{tabular}{|c|c|c|c|c|c|c|c|c|c|}
\hline & $\begin{array}{c}\text { Sci } \\
\text { Winter }\end{array}$ & $\begin{array}{c}\text { Sci } \\
\text { Spring }\end{array}$ & $\begin{array}{c}\text { POL } \\
\text { Winter }\end{array}$ & $\begin{array}{c}\text { POL } \\
\text { Spring }\end{array}$ & $\begin{array}{c}\text { NAO } \\
\text { Winter }\end{array}$ & $\begin{array}{l}\text { NAO } \\
\text { Spring }\end{array}$ & $\begin{array}{c}\text { AO } \\
\text { Winter }\end{array}$ & $\begin{array}{c}\text { AO } \\
\text { Spring }\end{array}$ & $\begin{array}{c}\text { SH } \\
\text { Winter }\end{array}$ \\
\hline Q gauged & $0.25^{*}$ & $0.27^{*}$ & - & $-0.28^{*}$ & - & 0.32 & $-0.28^{*}$ & - & -0.30 \\
\hline$Q$ recon & - & - & - & -0.31 & -0.32 & - & -0.34 & - & -0.32 \\
\hline
\end{tabular}

${ }^{1}$ Sci- Scandinavian index, POL - Polar Eurasian Pattern, NAO - North Atlantic Oscillation, AO- Arctic Oscillation, SH-Siberian High. 